\title{
I Rest My Case! The Possibilities and Limitations of Blockchain- Based IP Protection
}

Sofia Lopes Barata

CISUC, Department of Informatics

Engineering, University of Coimbra

Coimbra, Portugal

sofbarata@dei.uc.pt

\section{Paulo Rupino Cunha}

CISUC, Department of Informatics Engineering,

University of Coimbra

Coimbra, Portugal

rupino@dei.uc.pt

Ricardo S. Vieira-Pires

Center for Neuroscience and Cell Biology and

Institute for Biomedical Imaging and Life

Sciences (CNC.IBILI), University of Coimbra

Coimbra, Portugal

ricardo.pires@biocant.pt

\begin{abstract}
We have identified, mapped and discussed existing research on Blockchain-based solutions for intellectual property (IP) protection, an investigation that emerged from a case in antibody production for scientific and medical applications. To that end, we have performed a systematic literature review and created an instrument that classifies the contributions according to the materiality of the object they protect (from immaterial to physical), the type of protection (authorship notarization or prevention of illegal use) and the type of research (conceptual or empirical). Our results can be used to understand which avenues to pursue in the effort to create a new generation of more effective technology assisted IP protection systems, a priority for 152 signatory countries of the patent cooperation treaty.
\end{abstract}

Keywords: Antibodies, Blockchain, intellectual property.

\section{Introduction}

The global market for antibodies for research was valued at USD 2.52 billion in 2016 and it is anticipated to progress at a Compound Annual Growth Rate (CAGR) of 6.1\% over 2018-2025. Antibodies are high-value proteins produced in living cells and vastly used for scientific research, medical diagnostics, and advanced therapies, namely as biopharmaceutical drugs. They originate from two sources: native and in vitro. An animal, such as a rabbit, inoculated with a vaccine $\mathrm{X}$ will typically respond by producing Anti- $\mathrm{X}$ antibodies. These can either be recovered from the blood of the animal (native source, resulting in polyclonal antibodies (pAbs)) or they can be processed with advanced methodologies to collect the genetic (DNA) information that allows in vitro production (in vitro source, resulting in monoclonal antibodies (mAbs)). Biopharmaceutical and pharmaceutical companies are heavily dependent on the use of both, pAbs and mAbs for R\&D on innovative treatments for cancer and other chronic diseases, which has dictated a tremendous market traction. [35]. Monoclonal antibodies (mAbs) account for the leading share in this market. The in vitro molecular processing involved in their production enables the identification of very precise and unique genetic recipes for antibodies with specific capabilities (e.g. interacting with and killing a cancer cell). These recipes are nothing more than instructions in the form of a DNA sequence (a string of letters, A, T, G and 
C), that can be given to specialized living cells to produce the ultimate antibody molecule of interest. Importantly, this unique $\mathrm{mAb}$ recipe, becomes a high-value intellectual asset that requires special protection, since it can be used for replication and commercialization at an industrial scale. Patenting is a common route [9], but it can be very complex and costly, especially considering that the requirements needed to confer the patent may differ according to the countries in which it is applicable [20]. Additionally, patent enforcement of ten means expensive and long legal suits.

Thus, our research question is:

RQ: Are there Blockchain-based techniques suitable for the protection of immaterial intellectual assets, such as antibody recipes?

To investigate this issue, we started with a systematic literature review (SLR), which allows identifying, evaluating, and interpreting available research relevant to a topic area or phenomenon of interest, such as the summary of evidence concerning a given technology [7]. Our key concepts are (1) intellectual property (IP) and (2) Blockchain.

Intellectual property results from the work of the mind or intellect, which may be an idea, an invention or a process [32]. Depending on the adopted form of legal protection, the conferred rights will differ. Available forms are (1) patents, (2) trademarks, (3) copyrights, and (4) trade secrets [16], briefly described below:

- The patent is an exclusive right granted to an invention (product or a process), which prevents it from being commercially made, used, distributed, imported or sold without authorization of the patent owner [33]. It has a duration of 20 years and it is territorial, i.e., the rights are only applied in the country or region where the patent was granted, in accordance with the laws of that territory [33].

- Trademarks are used to distinguish companies, products or services by means of a word or symbol [16]. Legal owners can prevent its use by others within specific commercial limits. The trademark rights are valid for 10 years, but may be renewed indef initely [38] while the trademark is properly used and enforced [16]. It can be applied at the country or region level, or at the international level, depending on the type of registration [38].

- Copyright is an exclusive right assigned to the author or creator of a e.g. literary, artistic, musical, software products [16]. For content to be copyrightable it needs to (1) be permanently registered in some medium (e.g. paper, computer), (2) be original, and (3) exhibit creativity [16]. Copyright offers financial protection, enabling authors to license the use of their work for a fee, and also moral protection of non-economic interests [30], such as attribution or reputation. It has a finite duration that depends on the laws applied in the country / region of its use [16].

- Trade secrets are, as the nameimplies, secrets (e.g. formulas)that afford commercial or technical advantage [16] to a business because they are not known or easily discovered by observation [37]. Content may or may not be patentable, but if it becomes public the holder may lose all competitive advantage that the trade secret provides [16]. It has no legal protection and lasts only until discovered [16].

Blockchain is a technology originally introduced in the context of Bitcoin, to avoid the double spending of digital money, but whose underlying mechanisms have proven interesting to multiple areas where trust is a key concern [36]. This stems from the fact that transactions are recorded on a distributed, immutable, tamper-proof ledger, that is inherently auditable. Additionally, Blockchains can store and enforce smart contracts - pieces of code that are executed automatically once predetermined conditions are met - further reducing uncertainty and promoting confidence among stakeholders [28]. In the scope of our research we will focus on existing uses of Blockchain for the protection of intellectual property.

The remainder of this paper is structured as follows. Next, we describe the methodology, detailing how we obtained the data, then we present its analysis. Section 4 draws on the content of the identified papers to address the benefits, challenges, and practical applications of Blockchain-based IP protection. Section 5 maps extant research using a specially devised 
instrument that enables the discussion. The conclusions summarize our work and point out limitations.

\section{Methodology}

Our systematic literature review follows the structure defined by Webster and Watson [24]. Our goal is to identify and map relevant research about the use of Blockchain-based IP Protection. We selected the databases Science Direct (SD) and EBSCO, due to their wide coverage, complemented by AISEL for a focus on the Senior Scholars' Basket of Journals [34]. The paper search was made on the first and second weeks of November 2018. Originally, we chose the keywords "Blockchain" or "distributed ledger technology" (DLT) combined with "intellectual property" which are directly derived from the scope of our research. However, preliminary test searches in Google Scholar suggested the additional inclusion of "copyright" and "digital rights management" for the relevant hits they surfaced. The inclusion criteria were conference and journal papers, in English, published since 2008, given the fact that this was the year of publication of Nakamoto's article on Bitcoin, considered the first successful implementation of Blockchain technology [18]. Fig. 1 illustrates the search process.

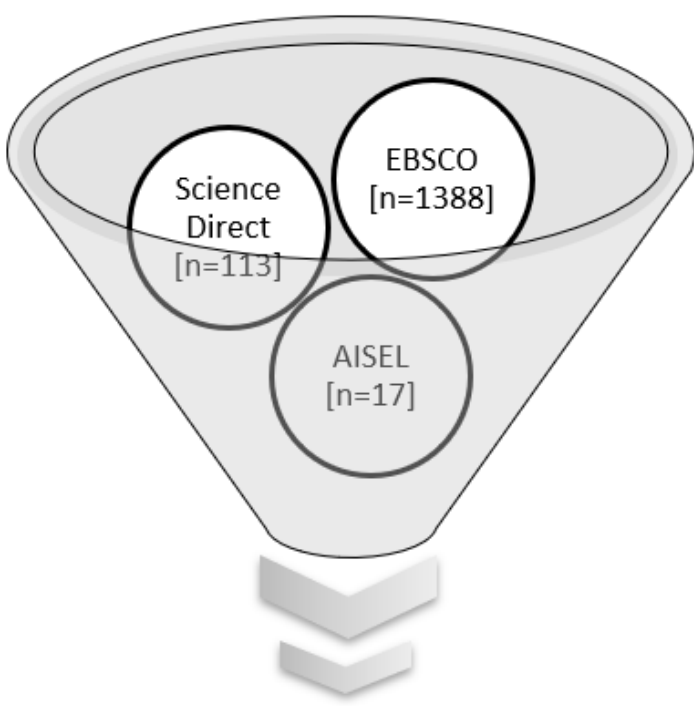

Full-text analysis

$[\mathrm{n}=20]$

\section{Keywords}

•("blockchain" OR "distributed ledger technology") AND ("intellectual property" $O R$ "copyright" OR "digital rights management")

Analysis \& Classification

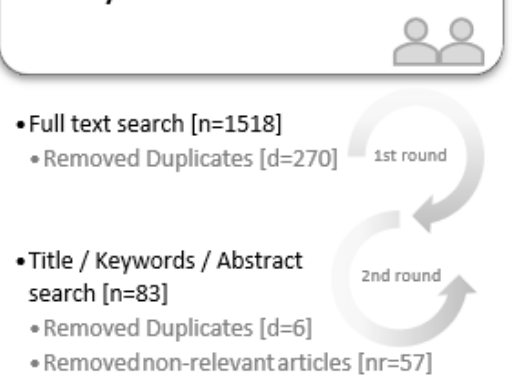

Fig. 1 - Systematic literature review approach

A full text search returned a total of 1518 hits (270 duplicates) on the selected set of databases. To narrow down the results, a second round was conducted using the same keyword combination, but constrained to title, keywords, and abstract. A total of 83 results were obtained at this stage. After eliminating six duplicates, our set was reduced to 77 articles. Two researchers separately analyzed the abstract of those papers and classified their relevance for the research (Yes / No / Maybe). After the triangulation of the results, including discussions on the "Maybes", 57 non-relevant articles were discarded and 20 remained to be analyzed in-depth, by reading the full text, with the aim of extracting information about the use of Blockchain for intellectual property protection.

\section{Data Analysis}

The papers selected for in-depth analysis have been classified in terms of year of publication, type of research (conceptual - C, empirical - E), object of protection (e.g. 
music, images, software), and type of protection discussed (Authorship Notarization - AN, Use Authorization - UA). Articles that evidence the use of Blockchain for the sole purpose of authorship attribution are marked AN. If the level of protection effectively prevents illegal use or dissemination of the object, then the articles are marked UA. For every article, a brief description of the role of Blockchain was included. Table 1 presents the classification of the 20 articles analyzed in-depth.

Table 1. Classification of the reviewed papers

\begin{tabular}{|c|c|c|c|c|c|c|}
\hline ID & Ref & Blockchain Use & $\begin{array}{c}\text { Type of } \\
\text { Object }\end{array}$ & $\begin{array}{c}\text { Type of } \\
\text { Protection }\end{array}$ & Year & $\begin{array}{r}\text { Type of } \\
\text { Research }\end{array}$ \\
\hline 1 & [17] & $\begin{array}{l}\text { Registration of creative work, namely } \\
\text { orphan work. With storage, dissemination, } \\
\text { and transfer of information about } \\
\text { copyright objects and their right holders. }\end{array}$ & $\begin{array}{c}\text { Creative } \\
\text { Work }\end{array}$ & $\mathrm{AN}$ & 2017 & $\mathrm{C}$ \\
\hline 2 & {$[1]$} & $\begin{array}{l}\text { Conception of a new ecosystem where it is } \\
\text { possible to identify the authors, track } \\
\text { protected content (stream), and assign a } \\
\text { fair remuneration to the artists. The } \\
\text { authors suggest that smart contracts could } \\
\text { allow music royalties to be administered } \\
\text { transparently and almost instantaneously. }\end{array}$ & Music & UA & 2018 & $\mathrm{C}$ \\
\hline 3 & {$[2]$} & $\begin{array}{l}\text { Normative analysis of key Blockchain } \\
\text { technology concepts from the perspective } \\
\text { of copyright law. Analyzes in detail the } \\
\text { legal issues related to smart contracts and } \\
\text { private ordering, copyright registrations, } \\
\text { the legal regime of DRM, and fair } \\
\text { remuneration. }\end{array}$ & Digital & $\overline{\mathrm{AN}}$ & 2018 & $\mathrm{C}$ \\
\hline 4 & [3] & $\begin{array}{l}\text { Establish ownership of the copyright, but } \\
\text { it also helps to enforce rights (e.g. artificial } \\
\text { intelligence could track unauthorized use } \\
\text { on the internet, this information would be } \\
\text { passed on to creators who could thus } \\
\text { contact the infringer directly). }\end{array}$ & Digital & $\overline{\mathrm{AN}}$ & 2018 & $\bar{C}$ \\
\hline 5 & [4] & $\begin{array}{l}\text { Analysis of the impact of blockchain on } \\
\text { intellectual property law, namely in the } \\
\text { registration, management and } \\
\text { enforcement of IP rights. The authors state } \\
\text { that Blockchain will be able to help to } \\
\text { overcome the IP register in different } \\
\text { legislations and dealing with different } \\
\text { procedures. }\end{array}$ & Generic & $\overline{\mathrm{AN}}$ & 2018 & $\mathrm{C}$ \\
\hline 6 & [5] & $\begin{array}{l}\text { Analysis the possibilities of Blockchain to } \\
\text { serve as an institution of property, and how } \\
\text { Blockchain applications may or may not } \\
\text { replace some aspects of legal norms and } \\
\text { property rights. }\end{array}$ & Digital & $\overline{\mathrm{AN}}$ & 2017 & $\mathrm{C}$ \\
\hline 7 & {$[6]$} & $\begin{array}{l}\text { Analysis of impact in the music industry, } \\
\text { such as, benefits, automating payments of } \\
\text { royalties (combining streams with smart } \\
\text { contracts), transparency and data } \\
\text { protection and the existing, and } \\
\text { compliance with legislation. }\end{array}$ & Music & $\mathrm{UA}$ & 2017 & $\mathrm{C}$ \\
\hline 8 & {$[8]$} & $\begin{array}{l}\text { Conception of a decentralized peer-to-peer } \\
\text { software license validation system using } \\
\text { cryptocurrency Blockchain technology. } \\
\text { Licenses are validated with a unique } \\
\text { license key that cannot be copied, reused, } \\
\text { or regenerated. This key links the user and } \\
\text { the device to the license. }\end{array}$ & Software & $\overline{\mathrm{UA}}$ & 2018 & $\mathrm{E}$ \\
\hline 9 & [10] & $\begin{array}{l}\text { Description of a Blockchain as a service } \\
\text { (BaaS) architecture for DRM business } \\
\text { models. Content is encrypted and stored in } \\
\text { a centralized database. The rights }\end{array}$ & Digital & UA & 2018 & $\mathrm{E}$ \\
\hline
\end{tabular}




\begin{tabular}{|c|c|c|c|c|c|c|}
\hline & & $\begin{array}{l}\text { confirmation and DRM assets } \\
\text { consumption are made with Blockchain. } \\
\text { Access to the data with tamper-resistant } \\
\text { copyrights protection, digital currency for } \\
\text { content consumption payment. }\end{array}$ & & & & \\
\hline 10 & {$[25]$} & $\begin{array}{l}\text { Description of a Blockchain-based scheme } \\
\text { for digital rights management, with two } \\
\text { isolated Blockchain application interfaces, } \\
\text { to store plain and cipher summary } \\
\text { information of original and DRM- } \\
\text { protected digital content. }\end{array}$ & Digital & UA & 2018 & $\mathrm{E}$ \\
\hline 11 & [13] & $\begin{array}{l}\text { Analysis the main transformations and } \\
\text { challenges that the record industry can } \\
\text { face with Blockchain technology. Improve } \\
\text { transparency, availability of copyright } \\
\text { data and facilitate the near-instant } \\
\text { micropayments for royalties. }\end{array}$ & Music & UA & 2018 & $\mathrm{C}$ \\
\hline 12 & [14] & $\begin{array}{l}\text { Conception of a smart contract for } \\
\text { managing digital reuse rights of research } \\
\text { data, recording the information of the } \\
\text { author and the conditions established for } \\
\text { the reuse of the work. }\end{array}$ & $\begin{array}{c}\text { Research } \\
\text { Data }\end{array}$ & AN & 2018 & $\bar{E}$ \\
\hline 13 & [15] & $\begin{array}{l}\text { Analysis the impact of Blockchain on } \\
\text { innovation in Scotland's digital design } \\
\text { industries. Blockchain can support } \\
\text { creative endeavor by enabling more } \\
\text { autonomous and flexible IP management } \\
\text { systems. }\end{array}$ & Digital & $\mathrm{AN}$ & 2017 & $\bar{C}$ \\
\hline 14 & [19] & $\begin{array}{l}\text { Focus on legal aspects related to } \\
\text { Blockchain under the copyright sphere. } \\
\text { The role of the Blockchain in the } \\
\text { distribution of copyrighted works in the } \\
\text { digital realm. }\end{array}$ & Generic & $\mathrm{AN}$ & 2018 & $\mathrm{C}$ \\
\hline 15 & {$[21]$} & $\begin{array}{l}\text { Analysis the possibilities of use and the } \\
\text { importance of Blockchain and smart } \\
\text { contract for attorneys. }\end{array}$ & Generic & AN & 2018 & $\bar{C}$ \\
\hline 16 & [22] & $\begin{array}{l}\text { Adequacy of traditional ideas about } \\
\text { property law in the context of digital } \\
\text { assets, namely the cryptocurrency Bitcoin. }\end{array}$ & Bitcoin & AN & 2017 & $\mathrm{C}$ \\
\hline 17 & [23] & $\begin{array}{l}\text { Possible use cases of IP management of } \\
\text { Blockchain technology. Blockchain can } \\
\text { create an immutable record of authenticity, } \\
\text { which may include ownership, evidence, } \\
\text { publication, and first and genuine use. } \\
\end{array}$ & Generic & $\mathrm{AN}$ & 2018 & $\mathrm{C}$ \\
\hline 18 & [26] & $\begin{array}{l}\text { Examination of Blockchain technologies } \\
\text { in the "creation of proprietary digital art } \\
\text { markets in which uncommodifiable digital } \\
\text { artworks are financialized as artificially } \\
\text { scarce commodities". }\end{array}$ & Digital Art & AN & 2018 & $\bar{C}$ \\
\hline 19 & [27] & $\begin{array}{l}\text { Outset of a Blockchain-based solution for } \\
\text { digital image rights management scheme. } \\
\text { With Internet misuse detection based on } \\
\text { watermark. }\end{array}$ & Digital & UA & 2018 & $\mathrm{E}$ \\
\hline 20 & [29] & $\begin{array}{l}\text { Conception of a Blockchain-based scheme } \\
\text { for an image copyright registry. A robust } \\
\text { image feature vector is used to identify } \\
\text { duplicate image registrations on the } \\
\text { network where it is being used. }\end{array}$ & Images & UA & 2018 & $\mathrm{E}$ \\
\hline
\end{tabular}

As shown in Fig. 2, the majority of papers (75\%) were published in 2018 and the remainder (25\%) in 2017, thus reflecting that the interest in the use of Blockchain technology for IP protection is recent and rising. Further, as seen in Fig. 3, 65\% of the articles were of conceptual nature and $35 \%$ of them empirical. 


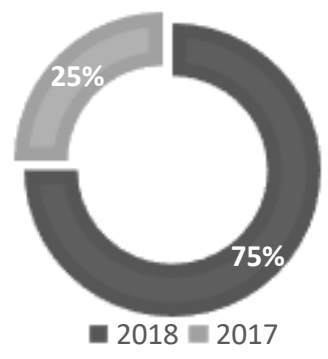

Fig. 2. Spread of papers selected by year

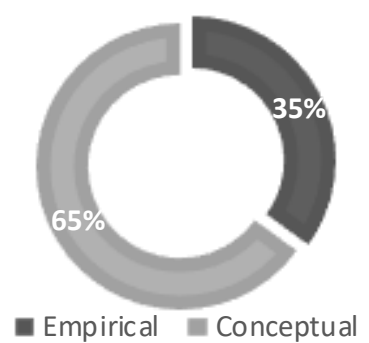

Fig. 3 - Spread of papers selected by type of analysis

Based on the content of the papers, in the next section we will outline the key benefits and challenges of Blockchain-based in IP protection. We will also present the use cases and examples found in the literature.

\section{What the Literature Says}

\subsection{Benefits of Using Blockchain for IP Protection}

Several authors have verified the feasibility of using Blockchain for the registration of intellectual property. The technology supports the technical, safety, and decentralization requirements for registering copyrights [17]. It can help provide tamper-proof evidence of ownership [17]. It also brings transparency and traceability over subsequent changes, increasing the visibility and availability of that information as a "Trusted Timestamping" [19], so the products are capable of "telling their own story", since their origin to commercialization [23].

Blockchain-based IP registers can replace existing IP databases [5, 17]. However, it is necessary to establish criteria, perform technical tests, and keep the interests of authors and users balanced [17]. The authors go further and claim that Blockchain may be considered an institution of property, such as a legal institution, but it is too early to predict whether it will replace legal norms and property rights [5]. The work of [4] also identifies the advantages of using a Blockchain-based IP system, such as simplifying the registration process, reducing associated fees, dispensing the need to register in different jurisdictions, and self-managing of IP rights by the author, without the involvement of third parties. In summary, the literature acknowledges advantages of Blockchain for IP registration, but cautions that it is not yet proven that it will be sufficient for the effective protection against illegal use of the object.

More recently, smart contracts became a central feature of Blockchain technology [4]. These software-based contracts enforced by the Blockchain can include specific conditions for sale or licensing [2,3]. Moreover, they enable property rights to be verified automatically [17]. Their main advantages are the possibility of control over the distribution [19], exploration of copyright-protected content [2], rewarding of the authors [1, 2, 6, 19], and enabling of nearinstant micropayments [13]. Smart contracts may also allow substantially lower transaction fees $[2,13]$ for both, rights-owners and users [19], without the need for intermediaries [1, 6, 13]. Nevertheless, complete disintermediation is seen by some authors as somewhat challenging [13], not desirable, or even impossible to occur in some fields [2]. It is argued that, in some cases, the intermediates may continue to be necessary [1], for example, to provide seed capital and help in negotiations. Some suggest that their roles may change [13]. Generally, the authors of the analyzed papers highlight the advantages of using smart contracts, namely in the protection and exploitation of copyright-protected content, however, there is no consensus of the role to be played by intermediaries in the future, if any.

\subsection{Challenges of Using Blockchain for IP Protection}

Blockchain is evolving fast, but there are major challenges to address. For example, the complexity of the technology and its promise of disruptive changes raises suspicion $\mathrm{s}$ and 
concerns [4]. Negative publicity associated with some use cases, like cryptocurrencies, also affects the rate of adoption of this technology [4]. The immutable nature of the Blockchain is one of its strengths, but also raises questions, such as responsibility if wrong data is registered [21].

Regarding the use of Blockchain in the context of IP protection, the literature identifies some concerns, such as, where the content will be stored: in the Blockchain proper or "offchain" [19]. In the latter case, some argue that using the Blockchain as a mere time-stamping service for "off-chain" content cannot guarantee reliability [19]. It is suggested that the use of Blockchain may disrupt the existing creative distribution networks, with [15] questioning how market will react to increased copyright control. Others question whether the "models of centralized finance will be far from being disrupted but rather reinforced" [26]. In a nutshell, literature points to some challenges inherent to the Blockchain technology, but also raises important issues related to implementation and market acceptance.

Intellectual property law has emerged as a way to prevent unauthorized distribution of creative expressions due to easy mechanical, technological, and digital reproduction [26]. Some papers have researched the articulation of Blockchain with traditional copyright law [17]. In Bodó and Quintais we can find a legal analysis of the assurances granted to technological protection measures (TPM), rights Management Information (RMI), and digital rights management (DRM) according to the international copyright law, and, in certain aspects, according with the civil law tradition of authors rights (European Union) and common law copyright (United States). It also identifies the copyright domains in which the implementation of the Blockchain can be promising and challenging: smart contracts and private ordering, copyright registries, the legal regime of DRM and fair renumeration. Blockchain-based IP protection lacks legal support and some work needs to be done in order to facilitate "user's trust in Blockchain records and their good faith usage of copyrighted works based on them need to be introduced (...) as well as the status of Smart contracts and their legal consequences" [19]. It is necessary to clarify, in legal terms, the roles of online intermediaries, and define the jurisdiction and the choice of law that will involve the Blockchain since there is no centralized management and it can be distributed across the world [21]. It is evident in some of the papers that we analyzed the concern with the impact that Blockchain will have on the current law and with its ability to meet the necessary legal requirements.

\subsection{Blockchain-Based solutions for IP Protection}

Most papers in our literature review briefly mention examples of Blockchain-based systems or algorithms; however, only six provide an in-depth description of existing solutions. The full list is presented in Table 2 .

Table 2. Examples of Blockchain-based IP Protection platforms mentioned in the papers

\begin{tabular}{|l|c|l|l|l|}
\hline \multicolumn{1}{|c|}{ Platform } & Ref. & \multicolumn{1}{c|}{ Blockchain Use } & Object & \multicolumn{1}{c|}{ URL } \\
\hline Ascribe & {$[15,17]$} & $\begin{array}{l}\text { Ascribe is no longer available. } \\
\text { CoalaIp (protocol for intellectual } \\
\text { property licensing) and BigChainDb } \\
\text { (Blockchain database) resulted from } \\
\text { the experience with this platform. }\end{array}$ & Digital Art & $\begin{array}{l}\text { https://www.ascribe.i } \\
\text { o }\end{array}$ \\
\hline $\begin{array}{l}\text { Open Music } \\
\text { Initiative }\end{array}$ & {$[1]$} & $\begin{array}{l}\text { Open-source protocol for the } \\
\text { uniform identification of music } \\
\text { right-holders and creators. }\end{array}$ & Music & http://open-music.org \\
\hline Choon & {$[4]$} & $\begin{array}{l}\text { Music streaming service and digital } \\
\text { payments ecosystem. }\end{array}$ & Music & https://choon.co \\
\hline $\begin{array}{l}\text { Blockai } \\
\text { (rebranded as } \\
\text { Binded) }\end{array}$ & {$[3,17]$} & $\begin{array}{l}\text { Blockchain solution for copyright } \\
\text { registration and monitoring of } \\
\text { images on several sources. }\end{array}$ & Images & https://binded.com \\
\hline Ujo & {$[4,6,13]$} & $\begin{array}{l}\text { Open platform built on Blockchain } \\
\text { technology, connecting music artists } \\
\text { and fans. Uses smart contracts for } \\
\text { agreements and payments. }\end{array}$ & Music & $\begin{array}{l}\text { https://www.ujomusic } \\
\text {.com }\end{array}$ \\
\hline
\end{tabular}




\begin{tabular}{|c|c|c|c|c|}
\hline Mycelia & {$[6,15]$} & $\begin{array}{l}\text { Blockchain music platform that aims } \\
\text { to facilitate payments, } \\
\text { collaborations, and partnerships. } \\
\text { Ecosystem of music creators and any } \\
\text { collaborators, publishers and } \\
\text { distributors that might be entitled to } \\
\text { a share of the value. It uses a } \\
\text { creative passport that stores profile } \\
\text { information, works, business } \\
\text { partners, and payment mechanisms. }\end{array}$ & Music & $\begin{array}{l}\text { http://myceliaformusi } \\
\text { c.org }\end{array}$ \\
\hline Muse & [6] & $\begin{array}{l}\text { Blockchain music platform with } \\
\text { payment management, such as } \\
\text { royalties, music sales, merchandise } \\
\text { and concert ticket sales. Registers } \\
\text { copyright information and licensing } \\
\text { conditions with smart contracts } \\
\text { (configuration of different fees for } \\
\text { using a song). }\end{array}$ & Music & http://www.muse.mu/ \\
\hline SoundChain & [6] & $\begin{array}{l}\text { A Blockchain Music Ecosystem } \\
\text { with streaming and automatic } \\
\text { royalty payment. Users can share a } \\
\text { link for a tune and receive a share of } \\
\text { the royalty payment if another user } \\
\text { listens to it. } \\
\end{array}$ & Music & $\begin{array}{l}\text { https://soundchains.n } \\
\text { et }\end{array}$ \\
\hline Bittunes & [6] & $\begin{array}{l}\text { A Blockchain Music Ecosystem } \\
\text { based on music streaming with } \\
\text { automatic royalty payment. }\end{array}$ & Music & $\begin{array}{l}\text { http://www.bittunes.c } \\
\text { om }\end{array}$ \\
\hline Kodak One & [15] & $\begin{array}{l}\text { Blockchain-based image rights } \\
\text { management platform with royalty } \\
\text { payments. The license is } \\
\text { documented in a smart contract with } \\
\text { copyright terms and conditions } \\
\text { associated with each image. }\end{array}$ & Images & https://kodakone.com \\
\hline Screener Copy & [15] & $\begin{array}{l}\text { Blockchain-based forensic } \\
\text { watermarking platform. Hosting, } \\
\text { uploading and secure distribution of } \\
\text { videos, with tracking of copies. }\end{array}$ & Videos & $\begin{array}{l}\text { https://www.screener } \\
\text { copy.com }\end{array}$ \\
\hline Aventus & [15] & $\begin{array}{l}\text { Blockchain-based event ticketing } \\
\text { protocol where creators can track } \\
\text { distribution and sales. Supports } \\
\text { event organizers and inventory } \\
\text { holders. Can track tickets as they } \\
\text { travel through the supply-chain. } \\
\end{array}$ & Tickets & https://aventus.io \\
\hline Monegraph & [26] & $\begin{array}{l}\text { Blockchain platform to register, } \\
\text { trade, sell and buy creative work. }\end{array}$ & Digital Art & $\begin{array}{l}\text { https://monegraph.co } \\
\mathrm{m}\end{array}$ \\
\hline Publica & [15] & $\begin{array}{l}\text { Blockchain end-to-end ecosystem } \\
\text { for publishing that allows the author } \\
\text { to obtain funds for the project and to } \\
\text { distribute eBooks to Publica e-reader } \\
\text { wallets. Automation of payments } \\
\text { between authors and supporters. }\end{array}$ & Books & https://publica.com \\
\hline Synereo & [15] & $\begin{array}{l}\text { Blockchain-enabled solution for } \\
\text { content publishing and distribution, } \\
\text { where the creator is paid whenever } \\
\text { his/her work receives a "like" or } \\
\text { "share". }\end{array}$ & Social Media & $\begin{array}{l}\text { https://www.synereo. } \\
\text { com }\end{array}$ \\
\hline
\end{tabular}

Half of the platforms in Table 2 are focused on the music industry. They enable registration of authorship and the fair remuneration for the use of the content. Of all the examples, only Ascribe is no longer available, and Blockai was rebranded as Binded. Next, we present the only six Blockchain-based systems that are discussed in-depth in the literature.

To prevent software piracy and preserve the rights of software vendors, Litchfield and Herbert have developed a Blockchain application, called ReSOLV [8]. It is a peer-to-peer software license validation (SLV) system that enables "software developers to protect 
copyrighted works" and prevents software interception and intrusion by malware. The operation is transparent to the user, with the license information being read from the Blockchain when the software is run.

In [10], [11], and [27] we can find the description of the design and implementation of a "Blockchain as infrastructure service for DRM business model", called DRMChain. This system stores the copyright information and enables the remuneration of authors in digital currency. Users can access digital content (e.g. videos, images), and if they do not have a license, they are redirected an acquisition and payment page. The latter is made directly to the author [10]. The protected content is encrypted [11] and uses a watermark mechanismfor image data to avoid illegal use inside the blockchain [27]. Whenever new content is uploaded, it is checked whether it is a copy of existing work. This paper fails to identify limitations and states that the system is "reliable, secure, efficient and tamper-resistance digital content service and DRM practice".

In [29], a Blockchain-based scheme for copyright management is described. A robust image feature is used to prevent duplicate in the blockchain. However, there are no mentions to mechanisms for remuneration based on usage.

Finally, Pãnescu and Manta used smart contracts to define the terms of reusing research data. The main goal is to ensure that authors control their research data, who accesses it (e.g. public or private) and under which terms. The end user of the research data benefits from a proof of compliance to the original work, opening an opportunity to integrate the proposal with existing blockchain platforms. However, this blockchain-based protection and tracing of research data also requires the participation of publishers and data repositories. The latter need to allow smart contract execution and the publishers need to confirm that the terms have been met before publication [14].

\section{Discussion and Outlook}

On the one hand, a vast majority of studies conclude that the use of Blockchain to register IP rights has clear advantages and can replace existing IP databases [5, 17]. On the other hand, "registering" is only part of the equation, and there are still crucial questions that remain unanswered, namely: (1) if Blockchain is enough to ensure intellectual property protection of digital objects, and (2) what could be the role of the Blockchain for different forms of IP.

Considering the main forms of intellectual property protection that we discussed: (1) patents, (2) trademarks, (3) copyrights, and (4) trade secrets [16], some research gaps have been identified. Only four of the reviewed papers mention the application of Blockchain to patents and trademarks. Furthermore, Ruzakova and Grin argue that patent and trademark registration systems do not require the use of Blockchain, because they are already managed at a governmental executive level [17]. Trade secrets are not addressed in any of the papers. Thus, these areas of IP protection should be included in future research agendas.

Most articles mention some application of Blockchain for registration and protection of copyrights. Copyright has also attracted theinterest of the European Parliament, where a reform was approved in March 2019. After intense debate, the modernization of the rules in current legislation must now be transposed to the internal codes of all EU members within the next two years [31]. This is the moment to address the role of emergent technologies in supporting the IP protection.

To make sense of the very different approaches to Blockchain-based IP protection identified in the literature, we have created the instrument presented in Fig. 4. It maps existing solutions and proposals according to three dimensions:

- The materiality of the object they protect, from purely immaterial (e.g. an antibody recipe), to digital goods (e.g. music or software), to physical products;

- The type of protection they afford (e.g. if the Blockchain mechanisms are used to "merely" prove authorship, or if they effectively prevent illegal use or dissemination of the protected object); 
- The type of research (e.g. conceptual, discussing possibilities, or empirical, discussing implemented systems or prototypes).

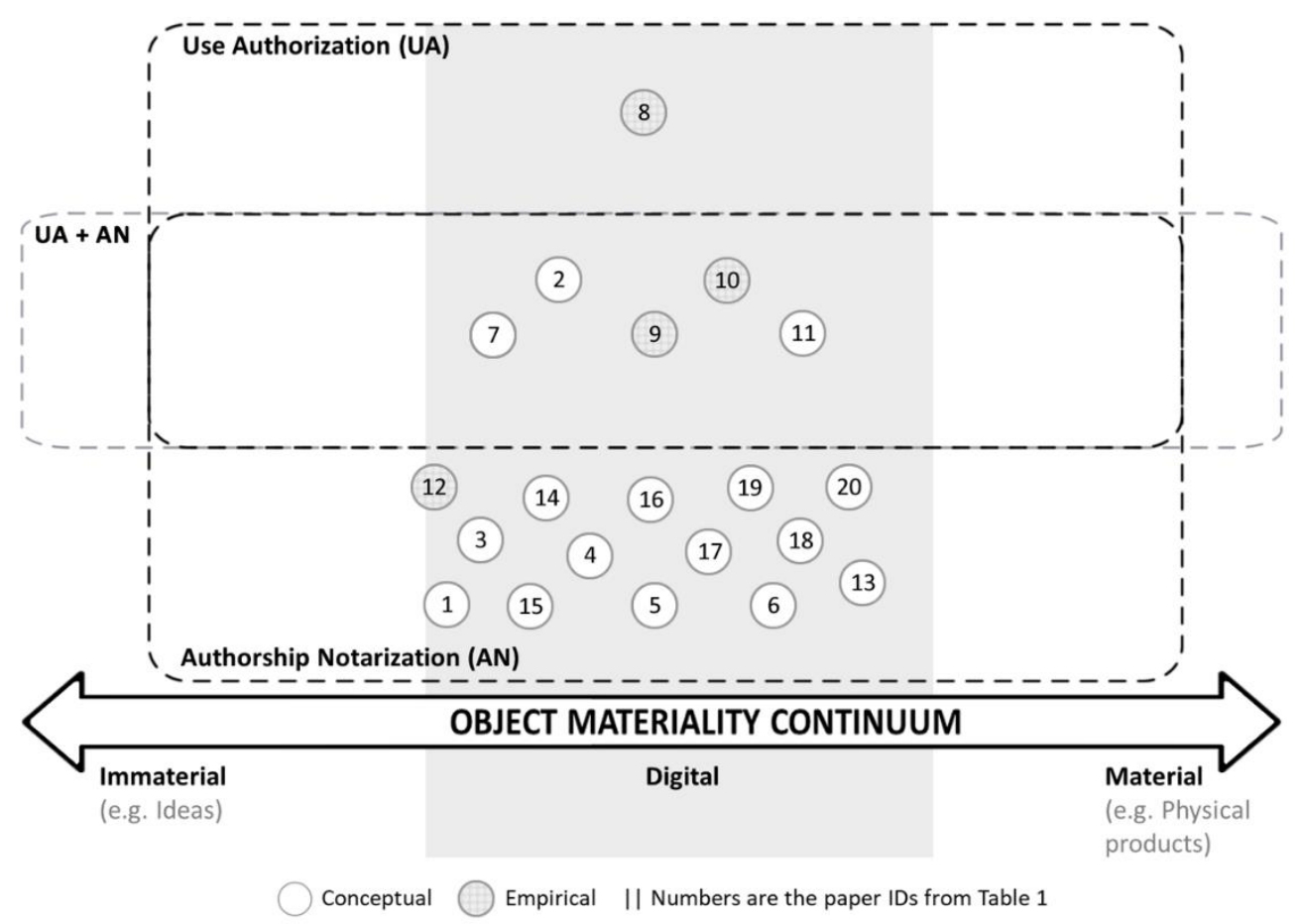

Fig. 4 - Papers classified by type of object, type of protection, and type of research

The first evident observation from the use of our instrument, in Fig. 4, is that all the identified literature focusses on the digital realm. No papers discuss the Blockchain-based protection of completely immaterial forms of IP. Likewise, no papers discuss the protection of IP embedded in physical products, at the other end of the continuum. Uncovering the reasons for this bias would be a relevant topic of research. Also, specific materialities may require or enable different mechanisms for protection.

A second observation is that the majority of papers focus on some form of authorship notarization and not on mechanisms to effectively prevent illegal use or dissemination of the protected object. Important as the former is, it suffers from many of the same disadvantages of traditional forms of protection, such as patents, namely the need to resort to justice to enforce the acquired rights - an inefficient, expensive, and time-consuming endeavor, often not feasible for small and medium enterprises (SMEs).

A third observation is that the vast majority of papers are conceptual, with few discussing actual implementations. This may be due to fact that we are still at the infancy of Blockchain [12], but it also suggests that future research should strive to experiment with the technology in real cases, using pilots and proofs-of-concept.

Finally, we will discuss the reviewed literature, mapped in Fig. 4, from the perspective of our research question. Apparently, no Blockchain-based solutions exist for the effective protection of immaterial intellectual assets, of which antibody recipes (instructions, in the form of DNA sequences) are an example. Once known, these recipes can be used by unauthorized parties to manufacture and sell those particular antibodies at scale. Some proposed solutions can be adapted to provide "proof" of authorship of the recipe, but (a) enforcement would still require resorting to courts, (b) the legal value of such Blockchain-based registrations of authorship is still being debated, and (c) such an approach does not effectively impede offenders from illegally producing and selling the antibody, as it is amply demonstrated by counterfeiters. Creating effective means for Blockchain-based protection of immaterial objects is, thus, a promising line of research. 


\section{Conclusion}

Departing from a need to protect intellectual property related to the production of antibodies for research, medical diagnostics, and advanced therapies, we carried out a systematic literature review on Blockchain-based IP protection. We identified and mapped a set of 20 relevant articles out of an initial 1518 hits that included duplicates and off-topic instances. Selected papers were read in full and their contributions categorized using a specially developed instrument. Several promising research avenues were proposed. No solution was identified that enabled the effective protection of an immaterial assets such as an antibody production recipe, thus validating our main line of work.

As limitations of this research we can point out the relativ ely limited number of databases that we searched foreligible studies, even if two of them, Science Direct andEBSCO, are major aggregators. Further, in a dynamic area like Blockchain, grey literature and market initiatives of ten contain recent advances not yet discussed in the academic literature.

\section{Acknowledgements}

This work is partially financed by national funds through the FCT - Foundation for Science and Technology, I.P., within the scope of the project CISUC - UID/CEC/00326/2019 and by the European Regional Development Fund (ERDF), through the COMPETE 2020 - Operational Programme for Competitiveness and Internationalization and Portuguese national funds via FCT Fundação para a Ciência e a Tecnologia, under projects projects POCI-01-0145-FEDER-030550 (BYDRUG) and POCI-01-0145-FEDER-007440 | UID/NEU/04539/2019 (CNC.IBILI).

\section{References}

1. Arcos, L.C.: The blockchain technology on the music industry. Brazilian J. Oper. Prod. Manag. 15 (3), 439-443 (2018)

2. Bodó, B., Gervais, D., Quintais, J.P.: Blockchain and smart contracts: the missing link in copyright licensing? Int. J. Law Inf. Technol. 26 (4), 311-336 (2018)

3. ENSIGN, D.: COPYRIGHT CORNER: Blockchain and Copyright. Kentucky Libr. 82 (3), $4-$ 5 (2018)

4. Gürkaynak, G., Yılmaz, İ., Yeşilaltay, B., Bengi, B.: Intellectual property law and practice in the blockchain realm. Comput. Law Secur. Rev. 34 (4), 847-862 (2018)

5. Ishmaev, G.: Blockchain Technology as an Institution of Property. Metaphilosophy. 48 (5), 666-686 (2017)

6. Khouri, G.: Music Licensing. Licens. J. 37 (7), 25-27 (2017)

7. Kitchenham, B., Charters, S.: Procedures for Performing Systematic Literature Reviews in Software Engineering. Keele Univ. Durham Univ. UK. (2007)

8. Litchfield, A., Herbert, J.: ReSOLV: Applying Cryptocurrency Blockchain Methods to Enable Global Cross-Platform Software License Validation. Cryptography. 2 (2), 10 (2018)

9. De Luca, C., Trifonova, A.: Expert Opinion on Therapeutic Patents Patent disclosure requirements for therapeutic antibody patents Patent disclosure requirements for therapeutic antibody patents. (2017)

10. Ma, Z., Huang, W., Gao, H.: Secure DRM scheme based on blockchain with high credibility. Chinese J. Electron. 27 (5), 1025-1036 (2018)

11. Ma, Z., Jiang, M., Gao, H., Wang, Z.: Blockchain for digital rights management. Futur. Gener. Comput. Syst. 89 746-764 (2018)

12. Mougayar, W.: The Business Blockchain: Promise, Practice, and Application of the Next Internet Technology. Hoboken, NJ John Wiley Sons, Inc. (2016)

13. O'Dair, M., Beaven, Z.: The networked record industry: How blockchain technology could transform the record industry. Strateg. Chang. 26 (5), 471-480 (2017)

14. Pãnescu, A.T., Manta, V.: Smart Contracts for Research Data Rights Management over the Ethereum Blockchain Network. Sci. Technol. Libr. 37 (3), 235-245 (2018)

15. Patrickson, B.: What do blockchain technologies imply for Scotland's digital design industry? 
ISPIM Innov. Conf. 1 (2018)

16. Poticha, D., Duncan, M.W.: Intellectual property-The Foundation of Innovation: A scientist's guide to intellectual property. J. Mass Spectrom. 54 (3), 288-300 (2019)

17. Ruzakova, O.A., Grin, E.S.: Application of Blockchain Technologies in Systematizing the Results of Intellectual Activity. Вестник Пермского Университета. Юридические Науки. 38 (38), 508-520 (2017)

18. Satoshi Nakamoto: Bitcoin: A Peer-to-Peer Electronic Cash System. (2008)

19. Savelyev, A.: Copyright in the blockchain era: Promises and challenges. Comput. Law Secur. Rev. 34 (3), 550-561 (2018)

20. Storz, U.: International intellectual property strategies for therapeutic antibodies. MAbs. 3 (6), 596-606 (2011)

21. Suzuki, B., Taylor, T., Marchant, G.: Blockchain: How It Will Change Your Legal Practice. Comput. Internet Lawyer. 35 (7), 5-9 (2018)

22. SZILAGYI, K.: a Bundle of Blockchains? Digitally Disrupting Property Law. Cumberland Law Rev. 48 (1), 9-34 (2017)

23. Vella, D., Falzon, M., Cassar, T., Valenzia, A.: Blockchain's Applicability to Intellectual Property Management. Licens. J. 38 (January), 10-13 (2018)

24. Webster, J., Watson, R. T.: Analyzing the Past To Prepare for the Future : Writing a Review. MIS Quartely. 26 (2), 12 (2011)

25. Yang, D., Li, M.: Evolutionary Approaches and the Construction of Technology-Driven Regulations. Emerg. Mark. Financ. Trade. 54 (14), 3256-3271 (2018)

26. Zeilinger, M.: Digital Art as 'Monetised Graphics': Enforcing Intellectual Property on the Blockchain. Philos. Technol. 31 (1), 15-41 (2018)

27. Zhaofeng, M., Weihua, H., Hongmin, G.: A new blockchain-based trusted DRM scheme for built-in content protection. Eurasip J. Image Video Process. 2018 (1), 1 (2018)

28. Zheng, Z., Xie, S., Dai, H., Chen, X., Wang, H.: An Overview of Blockchain Technology: Architecture, Consensus, and Future Trends. Proc. - 2017 IEEE 6th Int. Congr. Big Data, BigData Congr. 2017. 557-564 (2017)

29. Zhuvikin, A.: a Blockchain of Image Copyrights Using Robust Image. Int. J. Comput. Sci. Appl. 15 (1), 33-44 (2018)

30. Copyright, https://www.wipo.int/copyright/en/, Accessed: April 11, 2019

31. European Commission - PRESS RELEASES - Press release - Copyright reform: the Commission welcomes European Parliament's vote in favour of modernised rules fit for digital age, http://europa.eu/rapid/press-release_STATEMENT-19-1839_en.htm, Accessed: March 31, 2019

32. Intellectual Property | Definition of Intellectual Property by Merriam-Webster, https://www.merriam-webster.com/dictionary/intellectual property, Accessed: April 10, 2019

33. Patents, https://www.wipo.int/patents/en/, Accessed: April 10, 2019

34. Research - Association for Information Systems (AIS), https://aisnet.org/page/SeniorScholarBasket, Accessed: April 13, 2019

35. Research Antibodies Market Size \&amp; Share | Industry Report, 2018-2025, https://www.grandviewresearch.com/industry-analysis/research-antibodies-market, Accessed: April 11, 2019

36. The trust machine - The promise of the blockchain, https://www.economist.com/leaders/2015/10/31/the-trust-machine, Accessed: April 12, 2019

37. Trade Secrets | Definition of Trade Secrets by Merriam-Webster, https://www.merriamwebster.com/dictionary/trade secrets, Accessed: April 11, 2019

38. Trademarks, https://www.wipo.int/trademarks/en/, Accessed: April 11, 2019 